\title{
Shusterman on Europe, Entertainment, and Equality ${ }^{1}$
}

Stefán Snæevarr

Richard Shusterman is one of the world's most interesting aestheticians. He has been an advocate of pragmatist aesthetics; an aesthetics which emphasises the practical side of art and the aesthetic, while at the same time opposing any rigid separation between art and life or between high and low culture. Shusterman actually belongs to that rare breed of aestheticians, which takes popular culture seriously. He defends this kind of culture, maintaining that it speaks on behalf of ordinary folks. It is not by chance that the US, the country of the common Man, has been a stronghold of popular culture. In the first place, even though far from classless, America's social structure is arguable more flexible and more decentred than the structures of traditional European societies. Secondly, Americans have tended to be sceptical of European high culture because they had to fight for their independence from Europe. ${ }^{2}$ Thirdly, being a country of immigrants there has been no unique national tradition of high art. The fact that the American educational system is not centralized has weakened whatever possibilities there were for enforcing cultural uniformity. ${ }^{3}$ Fourthly, highbrow elitism has a much stronger position in Europe with its feudalistic traditions, than in democratic and egalitarian America. The notion of high art was invented by aristocrats to ensure their social privilege. Fifthly, there are national churches in (all?) European countries. The ecclesial tradition provided a strong and institutionally entrenched ideal of spiritualized experience and a tendency of pious attitudes towards works of art. Moreover, this tradition provided an intellectual priestly class that directed and regulated the propriety of this transcendental experience and its discourse. With secularization, the religious sentiments were projected into a religion of high art. Not so in America. It had weaker religious traditions than Europe ${ }^{4}$ and a dour Puritanism that was uncongenial to aesthetic appropriation. In the sixth place, American popular culture embodies a rebellious attitude towards the cultural hegemony of intellectuals in Europe. This is appealing to Europeans, especially the young, who find 
American popular culture an invaluable tool for liberation from cultural domination. $^{5}$

These six groups of statements about the US, Europe, equality and popular culture have certain, both explicit and implicit hypotheses as preconditions. Let us look at four of them:

(a) The more egalitarian a country is, the stronger the position of popular culture within that country;

(b) American popular culture enjoys worldwide popularity because of its egalitarian style, and/or because everything American is associated with egalitarianism;

(c) Europe has no popular culture to speak of;

(d) Europe is an entity of the same kind as the US. The USA is more egalitarian than Europe.

Now, I am not saying that there is any strict logical entailment between (a)-(d) and my initial six groups of statements about Shusterman's position. However, if (a)-(d) prove wrong, at least for the most part, then it is hard to see why one should believe in Shusterman's contention, unless I have misrepresented it in some grotesque fashion.

The rest of this paper will be devoted to a critical analysis of the hypotheses (a)-(d).

(a) Egalitarianism and popular culture: If feudal traditions and sharp class distinctions are the enemies of popular culture, how is it that the British have such a strong position in the realm of popular culture? British writers such as Sir Arthur Conan Doyle and Agatha Christie were responsible for the huge popularity of the whodunit, and what about the worldwide popularity of British fantasy fiction and books for children? Certainly, everybody has heard of books like Harry Potter, The Lord of the Rings, Peter Pan, Mary Poppins, the Narnia Books and Alice in Wonderland.

Popular music has a strong tradition in Britain; witness the music hall songs of the late 19th century and the first half of the 2oth century. Actually, the current strength of the musicals in London has roots back in the 19th century. ${ }^{6}$ Today's popular musical composers such as Sir Andrew Lloyd Webber have predecessors in the second to last century, Gilbert and Sullivan for instance. Furthermore, the very British Beatles caused the worldwide triumph of rock and the triumph of the English language as the lingua franca of pop music. For a while, British pop and rock almost eclipsed American popular music. ${ }^{7}$ Even though this is not the case anymore, the Brits still rock the world; thus, the British group 
Coldplay is thought to be the second biggest rock act in the world next to the Irish group $\mathrm{U}_{2}$.

Britain's neighbours, Belgium and France, also have feudalistic traditions and are far from egalitarian. Despite this, these countries have a thriving industry of comic books. People around the world enjoy reading about the adventures of Tintin and the Herculean feats of the endearing Gauls, Asterix and Obelix.

Additionally, the feudal Habsburg Empire was the motherland of operettas and waltzes, the pop and hip-hop of fin-de-siècle Western culture. No less than 1100 operettas of Austro-Hungarian origin were staged in Vienna between 1858 and 1938. Actually, Austria was one of the centres of international pop music in this era. ${ }^{8}$ Notice that the somewhat less feudal Wilhelmine German Empire could not really compete with the Habsburg Empire in the realm of popular tunes. ${ }^{9}$ This fact further weakens Shusterman's implicit contention that feudalism is no friend of popular culture.

Yet another country with a strong feudal tradition, Japan has a very powerful impact on modern popular culture. The fact that the country is a world leader in the making of animation movies serves as evidence. Furthermore, the Japanese have completely dominated the design and production of the computer games and their Pokemon-paraphernalia have enjoyed great global popularity. Japan is also the world leader in comics, producing $50 \%$ of all comic books. ${ }^{10}$

No countries in the world produce more action movies and light entertainment than India and Hong Kong. These countries are not renowned for their egalitarianism; India (in)famously suffering from the vestiges of an old caste system. Brazil is even less egalitarian and it is generally thought to be the country in the world with the least equal distribution of income. Nevertheless, Brazilians are famed for their samba songs and soap operas, which enjoy great international popularity. Their Argentine neighbours also live in an extremely unequal society. Despite this, they have created the vibrant popular culture of the tango. Actually, dance music from the LatinAmerican countries was very popular in the US during the 1940 and the 1950s, making such singers as Brazil's Carmen Miranda world stars.

Yet another case in point is the not exactly equal Venezuela; a country that produces soap operas en masse. These soaps are popular all over the Spanish-speaking world as anybody who has ever turned on a TV set in a Spanish hotel is liable to know.

Now, neither Nazi Germany nor the communist states were feudalistic, but they were inegalitarian in the sense that power was concentrated in the hands of the few and that the power elite led a much more comfortable 
life than the bulk of the population. All the same, they had their own entertainment industries, state-run in the communist case, state-controlled in the case of the Nazis. The infamous Nazi minister of propaganda, Joseph Goebbels, understood that in order to keep the masses happy, they had to be provided with bread and circus, but not necessarily direct propaganda. Thanks to him most of the movies produced in Nazi-Germany were light entertainment, with the odd propaganda movie thrown in for good measure. It has been calculated that only a low percentage of the feature films made in Germany during the Nazi era were outright propaganda or serious movies, while almost half of them were comedies or musicals, the bulk of the rest being adventure movies and suchlike. ${ }^{11}$ Fascist Italy was not very different; the neo-realism of Italian film in the first post-fascist years was a reaction against the glamour of Italian fascist movies.

Boring propaganda was perhaps the hallmark of communist movies, but the communist countries also made movies for entertainment. Even in the bleak Stalin era, the Soviets made lavish musicals and East Germans made Westerns, which were called Indian movies for politically correct reasons, in that the Indians were the nice guys, the cowboys the bad guys. ${ }^{12}$

These Indian movies were probably rather silly, but, notwithstanding, hypothesis (a) is refuted.

(b) Egalitarianism makes US entertainment popular: There might be a certain grain of truth in (b). For Sergio Leone and Federico Fellini, growing up in fascist Italy, watching American movies was a liberating experience. Indeed, it should not come as any surprise that by becoming acquainted with American popular culture after the war, the Italians, the Japanese and the Germans did themselves a world of good. They got to know a new kind of hero; the free spirited individual of, say the Western movies, who stood up against authority. This may have made them more receptive to the ideas of democracy and individual freedom. Some people, such as the Japanese writer Haruki Murakami, stress the liberating effect American culture had upon them. ${ }^{13}$ Further, the British learned rock and roll from the Americans and developed it in their own way. Interestingly enough, the British rock wave has been an important factor in changing the class structure in Britain as a lot of working class kids have hit the big time thanks to rock music.

However, we cannot infer from this bridging of social gaps in Britain that popular culture has an egalitarian content. It is even more difficult to prove that American popular culture is popular because of its supposed egalitarian nature; in fact, it does not seem that there are any compelling 
reasons to believe that its popularity has anything to do with egalitarianism. The culture of the rich and powerful has always been admired. Everybody imitated French fashion and culture when the not so very egalitarian France was on the top of the food chain just like the US nowadays. In the Third World and ex-communist countries, American consumer goods are symbols of affluence, not egalitarianism. In these countries, eating at McDonald's is an act of ostensive consumption, just as buying French clothes was in earlier times. So, in these lands distinctions are created with the aid of the supposedly egalitarian American culture.

Later, we shall see that the US is not nearly as egalitarian as Shusterman thinks and that there are even more reasons to doubt (b) than those I have hitherto discussed. For the time being, suffice it to say that even if there is a grain of truth in (b), it is probably not extremely big.

(c) No entertainment in Europe? We have already seen that neither Britain, France, Belgium nor Nazi-Germany did suffer or continue to suffer from any lack of popular culture. In reality, there has never been any shortage of entertainment in Europe. The Roman gladiator games were pure, if nasty, entertainment for the vulgar masses and the Elizabethan theatres provided entertainment for both rich and poor. So were the Greek theatres of antiquity which contained seats for up to 14.000 spectators. ${ }^{14} 15$ The modern Greek bouzouki music certainly is not aristocratic; it is a bona fide low-class cultural phenomenon. Despite this, it has become a part of Greek cultural identity ${ }^{16}$ and now enjoys worldwide fame. The popular music and dances of Ireland have also become a part of the Irish national identity. Who does not know Irish drinking songs or the river dance shows? And who has not heard of such Irish rock and/or pop acts as U2 or Westlife? The fact that Ireland has such a strong tradition for popular music speaks not only against hypothesis (b) but also against (a). For centuries Ireland was a truly feudal society where British lords subjugated the Gaelic-speaking majority.

Other European countries have been the cradles of such forms of popular entertainment as commedia dell'arte, opera buffa, ordinary operas, the operettas, the circuses, the revues, the cabarets, the Grand Guignol plays, ${ }^{17}$ the serialized novels and, last but not least, the movies. Now, if anybody objects to ordinary operas being called forms of popular entertainment, then one must bear in mind that operas started out as popular entertainment. ${ }^{18}$ In cities like Vienna, there were opera houses for the masses, the so-called Volksoper. Mozart's Magic Flute was originally staged in such an opera house, the audience consisting of just ordinary folks. It can be 
added that Europeans are still inventive in the field of popular culture, as can be seen from the fact that the Big Brother reality concept is of Dutch origin and that Idol is a British invention.

Worth mentioning and remembering is the fact that the noble art of moving images was invented in Europe, in France more precisely, and in the first years of movie making France was a world leader in film production. French filmmakers made, among others, commercial crime serials, the first sci-fi film ever, the first vampire movies and thrillers about the master criminal Fantômas. At that time, the Americans were importing more films from France than they were exporting to that country. ${ }^{19}$

Before the 1970s, the majority of European movies were made for commercial purposes. Among them were such global blockbusters as the Asta Nielsen silent movies, ${ }^{20}$ the first James Bond movies, Spaghetti westerns and Scandinavian soft porn. In actual fact, most European countries had their own film industry, which basically produced light entertainment. These film industries differed quite a lot from one another, reflecting each country's cultural tradition. In the first years after the Second World War, French cinema was dominated by an elegant and entertaining form of movies called cinema du papa. Light comedies starring comedians like Fernandel were the rage, not to mention the imbecile, semi-erotic movies starring sex kitten Brigitte Bardot. France's neighbour Germany was no less commercial. During the era of silent film, the so-called Berg movies and Heimat movies were extremely popular in Germany, the heroes of the Berg-movies being hikers, while the Heimat movies were cosy films about the good, old folks back home. In many ways, the 1950s were the golden age of the Heimat movies. In this decade, the Germans flocked to the theatres to watch costume dramas and loved the locally invented genre of melodramatic Artztfilme (movies about medical doctors). ${ }^{21}$ The Germans, though, were not the only Europeans to capitalize on their own traditions. The Italians exploited their opera tradition for all that it was commercially worth. They invented the epic movie before the First World War, making such international successes as Quo Vadis? and Calibria. In the 1960s, they revived this tradition and made mythological epics once again, featuring some true blue beefcakes parading as gods. These muscular gentlemen became gay icons in the USA. During the same period, the similar Italian Mondo Cane movies and the films about the cute little singer Robertino thrilled world audiences, singing the greatest Italian hit of all times $O$ solo mio. The British also had their own commercial film industry; remember the Bond movies. Alfred Hitchcock made his first thrillers in his native Britain and in the 1950 os and 6os the British Hammer 
studios dominated the global horror market, though they faced some competition from the Italian giallo (yellow) movies. At the same time, some witty Britons made the Carry-on movies, imbecile comedies for kids. The Monty Python movies were just as imbecile, but more British than steak and kidney pie. Note that just like Britain and Japan, Germany, France and Italy all have a feudal past. The fact that even feudalistic countries have had a thriving commercial film industry further weakens hypothesis (a).

As for the victory of American entertainment industry over its competitors, one explanation is that during the world wars filmmaking came to a virtual standstill in most European countries, leaving it to the American movies to fill the gap without difficulty. ${ }^{22}$ An even more important explanation is the fact that the film industries in virtually all European countries were only cottage industries, unlike their dynamic and streamlined American competitors. The early days of the American film industry saw the studios practicing vertical integration, buying or establishing theatres, which solely showed the movies of the studios. So, even if Denmark's Asta Nielsen was the first international film star, the idea of the film star came to fruition in Hollywood. The studios there methodically created the star system, making it a great vehicle for selling movies. On top of that, the Americans introduced Taylorism to the world of entertainment, for example producing dime novels on a kind of assembly line, so that one person invented the plot and another person wrote the love scenes etc. Tin Pan Alley was organized in a similar fashion, as was Hollywood. Its big studios were like factories, in stark contrast to the small European film industries. Attempts were made in some European countries to create something like a local Hollywood, for instance the UFA studios in Berlin, Cinecitta in Italy and the J. Arthur Rank Organisation in England. These little Hollywoods even created their own local star systems, with their stars occasionally catapulted to world fame; witness the success of Brigitte Bardot or such Italian actresses as Sophia Loren and Gina Lollobrigida. But these attempts were bound to fail in the long run, as most of the little Hollywoods were making movies in their local languages, hardly exportable to other countries. ${ }^{23}$ Moreover, a large chunk of their movies were about that which Danish scholar Mette Hjort has called the themes of nation, which were not easily understandable outside local contexts. ${ }^{24}$ I also think that commercial films in some European countries were sandwiched between Hollywood and local art movies. The latter often got government support, which drained resources from local commercial film industry, making its battle with Hollywood even more of an uphill fight. To make matters worse for the European filmmakers, the vastness of the 
United States gives Hollywood an edge over its competitors. It would not surprise me the least bit if this vastness made the products of the American film industry cheaper than those of other countries. Also, the density of screens is higher than in most European countries. That means that a film can play for fewer weeks in the US and reach the same number of potential spectators. ${ }^{25}$

In the 1920s, Hollywood could sell its movies to European theatres at something close to dumping prices. They were able to do so simply because they earned so much money at home, due to the size of the market. Add to this the fact that the American market for movies enjoyed what amounted to protection against foreign competition and you see that the European moviemakers were bound to lose. Moreover, it has been said that in the first years after the Second World War, the American authorities used direct and indirect pressure to strengthen the position of American movies in Europe, consciously promoting the American way of life as an antidote to communism. ${ }^{26}$ It is actually very difficult to see what vastness of markets, density of screens, economic protectionism and political pressure have to do with egalitarianism.

The European film industries began to crumble in the 1970 and 8os; symptomatically, the J. Arthur Rank Organisation stopped making movies in 1980 and the last Carry-On movie was made two years earlier. Just 40 years ago, only $35 \%$ of European box-revenues were earned by American films. Today, the figures are $80-90 \%$ in some European countries. ${ }^{27}$ To make matters worse, the market for European films in the US has almost disappeared. ${ }^{28}$ This disappearance has further weakened whatever is left of the European film industries. ${ }^{29}$ Actually, the present writer does not need these statistics, because he was raised on a healthy diet of both American and European commercial movies. When growing up in Iceland in the late 1950 s and early 6os, he alternated between American Westerns, the Jerry Lewis films, Danish comedies, Swedish children's movies about child detective Kalle Blomqvist and the German films about the teenyboppers Peter and Connie.

It is hard to see how the American take-over of the European movie market in the last 40 years and the disappearance of European film in the US have anything to do with equality. If equality was a causal factor, then surely America would have become more equal in this period and/ or Europe become less equal. But as we will see later, the development has gone in the opposite direction.

Similar things are happening in other realms of popular culture, for instance pop music. Before the Beatles, most countries around the globe had 
their local popular music. Occasionally, a song sung in French, German, Japanese or even Russian did make it to the charts in countries where these tongues were not spoken. Thus, in 1963 Kuy Sakamoto had a number one hit in the US with a song sung in Japanese, Sukyiaki. The same year, The Singing Nun from Belgium made it to the top of the American charts with her song Dominique, sung in French. ${ }^{30}$ This would be unthinkable now, as Anglo-American pop music has taken over completely.

Only 40 years ago, German charts were still dominated by local Schläger, i.e. pop tunes with a peculiar German sound, sung in German. ${ }^{31}$ A song like Freddy Quinn's Heimweh sold a couple of million copies in the late 195 os. $^{32,33}$ Some of the Schläger even became international hits; for instance, Lili Marleen or Marlene Dietrich's Ich bin von Kopf bis Fuß auf Liebe eingestellt. ${ }^{34}$ In the 1960s, German big band leaders like James Last and Bert Kaempert led their bands to international successes, Kaempert's band even reached the number one spot in the US in 1962. Later, one of his compositions, Strangers in the Night, became a huge international hit. ${ }^{35}$ The chances for a German musician to go that far in the US nowadays are extremely small. It is also almost unthinkable that a modern German artist would utilise the German Schläger tradition for political purposes like Bert Brecht and his composers Hanns Eisler and Kurt Weill did. Songs like Mackie the Knife are as German as Apfelstrudel.

Lists over German number one hits show us that until 1967 the overwhelming majority of the number ones were sung in German. ${ }^{36}$ Something similar probably holds for other European countries, including France. Just as Germany had its proud tradition of the Schläger, France had its pop music tradition of the chansons. Who has not heard of such popular French singers as Edith Piaf, Juliette Greco, Jacques Brel or Charles Aznavour? And who has not hummed a tune or two from the hugely popular French musical Les Misèrables?

After this long detour through the land of empirical facts, it is time to return to our American hero, Shusterman. He approvingly quotes Lawrence Levine, who talks as if a low-class, carnevalesque way of staging Shakespeare was a unique American phenomenon. ${ }^{37}$ But if we are to believe Charles Dickens and Oscar Wilde, a similar way of staging the great Bard's plays was common in British working class theatres. The storyteller of Wilde's The Picture of Dorian Gray describes a working class performance of Shakespeare and judges it as being extraordinarily vulgar. ${ }^{38}$ In Dickens's novel Great Expectations, a working class audience demands that Hamlet should sing Rule Britannia..$^{39}$ In Levine's description of the American staging, the audiences demanded that the actors sing Yankee Doodle Dandy. 
Chances are that these customs were imported from Britain, even though Levine does not mention it. So, Shusterman is not the only American scholar who automatically assumes that the US somehow monopolizes low-class culture. He is in other words not the only prominent American scholar who has a US-centric view of the world. But of course, this UScentrism is understandable in light of the fact that the US is leading in so many fields of culture and science. A further redeeming factor is the fact that American academics are not the only ones who are inward looking; French academics are even worse; they tend to be Franco-centric. ${ }^{40}$

Be that as it may, (c) is dead wrong. And in the course of responding to (c), we have found even further reasons to doubt (a) and (b).

(e) Comparing the US with Europe: Shusterman's sweeping generalizations about Europe do not hold water. There is no such thing as Europe; Europe is an American invention. Shusterman commits the American fallacy, speaking about Europe as if it was a country, not a continent. The inhabitants of the United States have a common national identity; in fact, they tend to be very patriotic. But this is not so in Europe; there is no real European identity, only a collection of different national identities, just like there are different national identities in the Western hemisphere. A Frenchman compares to a Portuguese like an American does to a Mexican when it comes to national identities, not like a Texan to a Californian or a Jewish-American to an African-American. Discoursing about Europe in Shusterman's typical American fashion is just like putting forth generalizations about the Western hemisphere or Eastern Asia. It could be added that until recently, the Spaniards identified more closely with Spanish speaking Latin America than with any European country, forming a common, popular cultural market with the Hispanics. Likewise, the Portuguese lived in a Portuguesespeaking world with their Brazilian and African cousins while the British were more interested in their empire than Continental Europe. And the French are still pretty much wrapped up in themselves. So creating a European identity could prove a Herculean task.

In contrast to what Shusterman seems to think, a sizable number of European countries do not have a national church; yet again we see a lack of a common denominator for these countries. Now, Shusterman hints at there being causal connections between the existence of such churches and the strength of popular culture and/or receptivity to American popular culture. If this was the case, then one would have expected countries without a national church to be more receptive to this culture, as well as having stronger popular cultures than those who have such a church. But the Scandinavians 
with their national churches are more receptive to American popular culture than the French, who do not have a national church.

As we remember, Shusterman talks like there is a strong tradition for philosophy and cultural elitism everywhere in Europe. The trouble is that most European countries have no philosophical tradition to speak of; we see here yet another example of a lack of a common European ground. Moreover, in countries like Iceland and Norway, people tend to frown upon abstract thinking and cultural elites. Nevertheless, the inhabitants of these two countries are more receptive to American popular culture than people in countries with a much stronger tradition for philosophy and cultural elitism; recall what I said about the French being less taken by American popular culture than the Scandinavians. This further weakens Shusterman's contention that young Europeans are attracted to American popular culture because of its liberating effect. Moreover, this weakens hypothesis (b).

Now to the question of whether or not Europe is less equal than the US: If Shusterman by egalitarian means egalitarian in terms of income then the majority of Western European countries (including the Nordic ones) is much more egalitarian than the US. The basic problem in some of the Nordic countries is oppressive egalitarianism, not lack of equality. America's strength lies in its individualism, dynamic ways, creativity and great diversity, not its egalitarianism. Nevertheless, Shusterman has a point when he says that the American class structure has traditionally been less rigid than that of the major European countries. ${ }^{41}$ But, in the first place, there are signs of this being a thing of the past. Recent research points in the direction of there being more social mobility within the Nordic countries and Germany than in the US. ${ }^{42}$ This development has taken place over the last 25 years, the period in which the US took a decisive lead in most aspects of popular culture; even rock music, the old domain of the Britons. So the US reached economic equality in the same period as it acquired predominance in the sphere of popular culture. This fact hardly strengthens Shusterman's implicit conjecture about egalitarianism creating the preconditions for the flourishing of popular culture.

Secondly, if Shusterman by egalitarian means egalitarian in terms of culture, then he is wrong again. There are large parts of Europe where cultural equality is greater than in the USA. In the Nordic and Eastern European countries, the general level of education is quite high and it is not unusual that ordinary people are thoroughly well-read and highly cultivated. In Russia, Europe's most populous country, there are scores of poor old babushkas that know Pushkin's poems by heart. Furthermore, quite a number of leading Nordic writers started out as ordinary workingmen. 
That illustrious list includes the Nobel Prize winners Knut Hamsun and Harry Martinsson, both raised in abject poverty. So, if Shusterman thinks that the upper classes monopolize the fine arts or that there are no egalitarian cultures in Europe, then he is dead wrong.

In addition, it simply is not true that all European countries have feudal traditions, Iceland and Norway being cases in point. Besides, the US had slavery longer than any Western European country. It is, of course, well known that African-Americans were discriminated against long after the abolition of slavery. Further, the Native Americans have had a hard time, to put it mildly, almost as hard as Jews and Gypsies in certain European countries. Jews were also victims of discrimination in the US, albeit much more mildly, before the war. It is said that it was almost impossible for a Jewish academic to get a professorship in an American University before 1945. It can be added that in Arthur Miller's play Broken Glass, one of the characters is a Jewish doctor who went to Germany (of all places) in the 1920 in order to study because he was unable to get into American medical school as a result of his ethnic origin. Interestingly enough, the Jews who laid the foundation for Hollywood left the East Coast to get away from the ruling Yankee establishment. ${ }^{43}$ So, maybe Hollywood rose out of discrimination, not egalitarianism. In a new documentary, highlighting the history of Jewish popular culture in America, it is understood that at the beginning of the last century, many Jews entered into show business because of discrimination. They did not have many other options. These are among the reasons why there has been such a strong Jewish impact on jazz and other forms of American popular music. If the US had been more egalitarian, then far fewer Jews would have worked in show biz and, as a consequence, perhaps American popular culture would not have had the enormous strength it has today. To this it may be added that discrimination of blacks could be one of the reasons for their great impact on American popular culture. Until recently, popular culture was one of the few venues that African-Americans had for striking it rich. Now it is sometimes said that the working classes in Britain were the blacks of British society. Remember that the British working class kids used rock as a means of breaking class barriers. Had Britain been less of class society in the 1960s, then the working class kids could have made it without playing rock and roll. The working class kids might have found other ways, besides that of rock and roll, to better their lot. The implication is that had Britain been more egalitarian, then it might not have been so influential in popular music. If this is true, then we have less of a reason to believe in hypothesis a) than we already have. 
In the light of the aforementioned facts, maintaining that the US is a paragon of egalitarian virtues is plainly preposterous and, therefore, (d) is undoubtedly wrong. In the course of criticizing (d), we have found further reasons to doubt (a) and (b).

My conclusion is that hypotheses (a), (c), and (d) are blatantly wrong while there is probably a grain of truth in (b). We can summarize the contents of this article in the following fashion: In the first place, the US does not monopolize popular culture; there is and there never has been any lack of such culture in Europe. Secondly, comparing a country, the US, with a continent, Europe, is not very fruitful. Thirdly, the United States is not necessarily more equal than a host of European countries. Fourthly, equality does not seem to be a better breeding ground for popular culture than inequality.

In the course of refuting these four hypotheses, we have also been criticizing US-centrism. Shusterman's US-centrism is evident from the fact that he talks about popular music as if it was the exclusive domain of the supposedly egalitarian Americans. However, he only analyzes such arch-typical American forms of music like rap and country. ${ }^{44}$ He hardly ever mentions kinds of popular music in which Europeans have had a strong say, for instance rock, pop and techno, the last being a German invention.

Shusterman is well advised in ridding himself of US-centrism, as well as revising and strengthening the empirical part of his otherwise excellent theorizing.

\section{Notes}

1. This paper is in many ways a sequel to my "Pragmatism and Popular Culture: Shusterman, Popular Art and the Challenge of Visuality", Journal of Aesthetic Education, Vol. 41, No. 4 (Winter 2007).

Thanks to Audun Engelstad, Jan Anders Diesen, Søren Birkvad and the referees of this journal for valuable comments. Thanks to Denise McVeigh for improving upon my English.

2. Shusterman seems to have forgotten that the US liberated itself from Great Britain with the assistance of a European country, namely France that footed the bill for the war of independence.

3. I thought that McDonald's and Coke did the job!

4. This is a strange statement indeed; taking into account the fact that religion has much stronger position in the US nowadays than in the overwhelming majority of the European countries.

5. Richard Shusterman, Pragmatist Aesthetics: Living Beauty, Rethinking Art 
(New York: Routledge, 1992), 196-198.

6. Popular musicals such as Cats, Evita, Grease and Rocky Horror Show are all British and were originally staged in London. Chess was composed by Swedish tunesmiths but also originally staged in London.

7. According to the Norwegian daily Aftenposten (February 2, 2001), the three best-selling groups of all times in the US are British. In addition, 22 years ago, $36 \%$ of all records sold in the States were British. By the end of the 1980 , $35 \%$ of all records sold worldwide had their origin in the UK and by far the best-selling pop group of all times everywhere is of course the Beatles. Further, American hit lists show that from 1963-1997 British songs regularly made it to the number one position in the US. In the last ten years, however, the position of British pop and rock in the USA has weakened considerably. This can be seen from the Billboard Hot Hundred, easily obtainable on the Internet, for instance via http:// en.wikipedia.org/wiki/List_of_number-one_hit (United States).

8. Roman Sandgruber, Illustrierte Geschichte Österreichs (The Illustrated History of Austria) (Vienna: Pichler Verlag, 2000), 153.

9. According to Carl Schorske, those who won a patent of nobility in the Habsburg Empire were not admitted to the court, in contrast to the German imperial court. This is one of many indications of Austria having been more feudal than Germany. Carl E. Schorske, Fin-de-siècle Vienna: Politics and Culture (Cambridge: Cambridge University Press, 1961), 7.

10. I have my information from a recent program on comics, shown on the Discovery Channel. But one does not need such programs to know that this is true. Just walk into any child's room in the Western world and you will see a lot of Japanese stuff.

11. Mary-Elizabeth O'Brien, Nazi Cinema as Enchantment: The Politics of Entertainment in the Third Reich (Rochester, NY: Camden House, 2004), 8-9.

12. Daniela Berghahn, Hollywood Behind the Wall: The Cinema of East Germany (Manchester and New York: Manchester University Press, 2005), 42--43.

13. Ian Buruma, "Becoming Japanese," The New Yorker, December 23 \& 30, 1996.

14. Rob Graham, Theatre: A Crash Course (Leicester: Silverdale Books, 1999), 16.

15. In all fairness, it should be mentioned that Shusterman talks about the popularity and raucous nature of Greek and Elizabethan theatre in Richard Shusterman, Pragmatist Aesthetics: Living Beauty, Rethinking Art (New York: Routledge, 1992), 181. But he does not seem to understand that this fact weakens his theory about European lack of popular culture.

16. This kind of music was frowned upon by many Greeks when it was brought to Greece proper by Greek refugees from Turkey in the 1920s. However, blues and country were also frowned upon by the white, American middle and upper 
classes. The process that made these forms of music accepted is a part of a worldwide process, which can be called the triumph of the common Man. Of course, the USA contributed heavily to this victory, as we see from the title of Aaron Copland's composition Fanfare for the Common Man. But until the 1960s, the one who passed for the common Man in the States was actually a white middle class male!

17. The Grand Guignol was a 19th century French theatrical art form of short plays with emphasis on sensational violence and horror (Kieran, 2003, 464).

18. William Irwin, "Philosophy Engages Popular Culture: An Introduction," in Philosophy and the Interpretation of Popular Culture, eds. William Irwin and Jorge J. E. Gracia (Lanham: Rowman \& Littlefield Publishers Inc, 2006), 1-18, 7.

19. Harvey Feigenbaum, "The Economics of Dumbing Down. Hollywood: The Bottom Line," Le monde diplomatique, August 2005.

20. Danish Asta Nielsen was the first international film star in history, before and during the First World War. She made silent movies in her native Denmark. Actually, soldiers died in the trenches with her picture in the knapsack.

21. Daniela Berghahn, Hollywood Behind the Wall: The Cinema of East Germany (Manchester and New York: Manchester University Press, 2005), 39.

22. Harvey Feigenbaum, "The Economics of Dumbing Down. Hollywood: The Bottom Line," Le monde diplomatique, August 2005.

23. Most of my information about film history in this paper comes from Naughton and Smith (2003), Gronemeyer (1998), Schneider (2003), O'Brien (2004) and Berghahn (2005). I have also picked up a thing or two from various TV documentaries. The bit about the German Berg and Heimat movies I got from a documentary on Leni Riefensthal. In a similar fashion, my information about Fellini and Leone was picked up from documentaries on these illustrious filmmakers, and most of what I say about the entertainment industry in non-Western countries and the communist states stems from a series of documentaries, hosted by Debbie Harry of Blondie fame, which was shown on the Discovery Channel. Actually, documentaries are my sources for several other titbits of information and the same holds for the Internet, not least Wikipedia. It is, for instance, my main source of information about the J. Arthur Rank Organisation and the Carry-On movies. A further source is my friend Jan Anders Diesen, professor of film and TV studies at the University College of Lillehammer, Norway.

24. Daniela Berghahn, Hollywood Behind the Wall: The Cinema of East Germany (Manchester and New York: Manchester University Press, 2005), 7.

25. David Puttnam, The Undeclared War: The Struggle for Control of the World's Film Industry (London: HarperCollins Publishers, 1997), 320.

26. Stephen J. Walton, Den teksta versjonen: Amerikanisering og modernitetens intellektuelle (The Dubbed Version: Americanization and the Intellectuals of Moder- 
nity) (Oslo: Det norske samlaget, 2006), 164-174.

27. David Puttnam, The Undeclared War: The Struggle for Control of the World's Film Industry (London: HarperCollins Publishers, 1997), 332.

28. Ibid., 322.

29. German film director Volker Schlöndorff confirms this in an article published in Der Spiegel in the fall of 1998. In the 1960s, one third of all movies shown in an average European country were homemade. Another third came from other European countries and the rest from the US. Nowadays (in 1998), at least $75 \%$ of the movies were American.

3o. http://en.wikipedia.org/wiki/List of number-one hit (United States).

31. For an analysis and overview of its history, see the entry on Schlager in the German Wikipedia. A chilling part of this history is the fact that several JewishGerman songwriters were murdered by the Nazis. http://de.wikipedia.org/wiki/ Schlager.

32. Wilfried Berghahn, "In der Fremde. Sozial-psychologische Notizen zum deutschen Schlager," ("Away From Home. Social-psychological Notes on German pop songs") Frankfurter Hefte: Zeitschrift für Kultur und Politik 17, no. 3 (1962), 195.

33. Ibid. 200-1. Wilfred Berghahn's witty analysis of how the Schläger captured the German Zeitgeist at various points in Germany's history is worth reading. He points out that in Germany in the late 1950s American rock and roll was just absorbed by its mainstream sugary pop music. While American rock and roll was non-conformist and rebellious, the lyrics of German Schläger of the period stressed the virtues of conformity. Germany is, or at least was, a less individualistic society than the US, which probably explains the difference between pop music in those countries at that time. American rock and roll probably did German kids a favour, teaching them individualistic virtues.

34. This song is known in the English-speaking world as Falling in Love again.

35. Once again, the Wikipedia is my source of information, the entry on Kaempfert. http://en.wikipedia.org/wiki/Bert_Kaempfert

36.http://de.wikipedia.org/wiki/Liste_der_Nummer-Eins-Hits_in_Deutschland

37. Lawrence Levine, High Brow/Low Brow: The Emergence of Cultural Hierarchy in America (Cambridge, Mass: Harvard University Press, 1988), 13-81. Richard Shusterman, Pragmatist Aesthetics: Living Beauty, Rethinking Art (New York: Routledge, 1992), 296n.

38. Oscar Wilde, The Picture of Dorian Gray (Köln: Könneman, 1992), 61-64.

39. Charles Dickens, Great Expectations (Ware: Wordsworth Classics, 1992), 210.

40. Take Pierre Bourdieu as an example. He generalizes about cultural consumption in the Western world, based on studies in France alone. Pierre Bourdieu, 
Distinction: A Social Critique of the Judgement of Taste (Translation from French) (Cambridge, Mass: Harvard University Press, 1984).

41. Richard Shusterman, Pragmatist Aesthetics: Living Beauty, Rethinking Art (New York: Routledge, 1992), 197.

42. Greg J. Duncan et al., "No Pain, No Gain? Inequality and Economic Mobility in the United States Canada and Europe," in Poverty and Economic Inequality in Industrialized Western Societies, ed. N. Keilmann, J. Lyngstad, H. Bojer and I. Thomsen (Oslo: Scandinavian University Press, 1997), 257-275. Jo Blanden, Paul Gregg and Stephen Machin, Intergenerational Mobility in Europe and North America (London: Centre for Economic Performance, 2005).

43. Anonymous, "Ces juifs qui ont fait Hollywood," ("The Jews who made Hollywood") Le Point, no. 1692, February 17, 2005, 75.

44. As for his analysis of country, he has written a very charming piece on country musicals in Richard Shusterman, Performing Live (Ithaca and London: Cornell University Press, 2000), 76-95. For his very inspiring defence of rap music, see for instance Richard Shusterman, Pragmatist Aesthetics: Living Beauty, Rethinking Art (New York: Routledge, 1992), 201-235.

\section{Referemces}

Anonymous. "Ces juifs qui ont fait Hollywood" ("The Jews who made Hollywood"). Le Point, no. 1692, February 17, 2005.

Berghahn, Daniela. Hollywood Behind the Wall: The Cinema of East Germany. Manchester and New York: Manchester University Press, 2005.

Berghahn, Wilfried. "In der Fremde. Sozial-psychologische Notizen zum deutschen Schlager" ("Away From Home. Social-psychological Notes on German pop songs“). Frankfurter Hefte: Zeitschrift für Kultur und Politik 17, no. 3 (1962): 193-202.

Blanden, Jo, Paul Gregg and Stephen Machin. Intergenerational Mobility in Europe and North America. London: Centre for Economic Performance, 2005.

Bourdieu, Pierre. Distinction: A Social Critique of the Judgement of Taste (Translation from French). Cambridge, Mass: Harvard University Press, 1984.

Buruma, Ian. "Becoming Japanese." The New Yorker, December 23 \& 30, 1996.

Dickens, Charles. Great Expectations. Ware: Wordsworth Classics, 1992.

Duncan, Greg J. et al. "No Pain, No Gain? Inequality and Economic Mobility in the United States Canada and Europe." In Poverty and Economic Inequality in Industrialized Western Societies, edited by N. Keilmann, J. Lyngstad, H. Bojer and I. Thomsen, 257-275. Oslo: Scandinavian University Press, 1997.

Graham, Rob. Theatre: A Crash Course. Leicester: Silverdale Books, 1999.

Gronemeyer, Andrea. Film (translated from German). Hauppage NY: Barron's Educational Series, 1998. 
Feigenbaum, Harvey. “The Economics of Dumbing Down. Hollywood: The Bottom Line." Le monde diplomatique, August 2005.

Irwin, William. "Philosophy Engages Popular Culture: An Introduction." Philosophy and the Interpretation of Popular Culture, edited by William Irwin and Jorge J.E. Gracia, 1-18. Lanham: Rowman \& Littlefield, 2006.

Kiernan, Matthew. "Art and Morality." In The Oxford Handbook of Aesthetics, edited by J. Levinson, 451-470. Oxford University Press: Oxford, 2003.

Levine, Lawrence W. High Brow/Low Brow: The Emergence of Cultural Hierarchy in America. Cambridge, Mass: Harvard University Press, 1988.

Naughton, John, and Adam Smith. Movies: A Crash Course. Leicester: Silverdale Books, 2003.

O'Brien, Mary-Elizabeth. Nazi Cinema as Enchantment: The Politics of Entertainment in the Third Reich. Rochester, NY: Camden House, 2004.

Puttnam, David. The Undeclared War: The Struggle for Control of the World's Film Industry. London: HarperCollins Publishers, 1997.

Sandgruber, Roman. Illustrierte Geschichte Österreichs (The Illustrated History of Austria). Vienna: Pichler Verlag, 2000.

Schneider, Stephen Jay. 1001 Movies You Must See Before You Die. Cassell: London, 2003.

Schorske, Carl E. Fin-de-siècle Vienna: Politics and Culture. Cambridge: Cambridge University Press, 1961.

Shusterman, Richard. Pragmatist Aesthetics: Living Beauty, Rethinking Art. New York: Routledge, 1992.

Shusterman, Richard. Performing Live. Ithaca and London: Cornell University Press, 2000.

Walton, Stephen J. Den teksta versjonen: Amerikanisering og modernitetens intellektuelle (The Dubbed Version. Americanization and the Intellectuals of Modernity). Oslo: Det norske samlaget, 2006.

Wilde, Oscar. The Picture of Dorian Gray. Köln: Könneman, 1992.

http://en.wikipedia.org/wiki/List_of_number-one_hit (United States)

http://en.wikipedia.org/wiki/Bert_Kaempfert

http://de.wikipedia.org/wiki/Schlager

http://de.wikipedia.org/wiki/Liste_der_Nummer-Eins-Hits_in_Deutschland. 